\title{
Semiotics of ideology
}

\author{
WINFRIED NÖTH
}

If an 'ideology', in its broadest sense, is 'a system of ideas', semiotics, the study of sign systems, is predestined to make essential contributions to the study of ideologies. The semiotic approach to the study of ideology begins with an investigation of the concept itself, which has changed considerably in the course of its history. Theoretical semiotics has studied signs of ideologies and ideologies as sign systems, and applied semiotics has developed critical instruments to reveal the ideological foundations of media discourse, but critical semiotics has not only been critical of the discourse of 'the others'; it has gone so far as to raise the self-critical question whether the discourse of semiotics itself has ideological foundations.

\section{Semiotic roots of ideology}

The concept of ideology has changed throughout its history and, until today, has remained controversial. Historically, 'ideology' was first used to designate the ideas of a particular group of scholars in France. Today, the term is situated between a value-neutral and merely descriptive concept and a polemic, or even pejorative sense. For the theory and the concept of ideology, see Plamenatz (1970), Dierse and Romberg (1976), Thompson (1990), Eagleton (1991), and Choe (1997).

The term ideology was first used in 1796 by Antoine Louis Claude Destutt de Tracy (1754-1836) to designate a new empiricist 'science of ideas'. De Tracy developed the fundamentals of this new theory in his Eléments d'idéologie (1801-1815, 5 vols.). Together with E. B. de Condillac, P. J. G. Cabanis, and A. Helvétius, Destutt de Tracy belonged to a group of philosophers who were also called ideologists ('idéologues'). Their philosophy had a sensualistic orientation and was opposed to Descartes's rationalism. The ideologists wanted to define cognitive processes in terms of sensory activities and consequently considered their study of ideas as a branch of biology. 
The programmatic goal of this first 'ideology' was a study of the 'origins of ideas', which was to be free from metaphysical and religious prejudices. The ideologists' political program was democratic and in accordance with the ideals of the Age of Enlightenment. Therefore, it soon came into conflict with the policy of Napoleon, who attacked and ridiculed these philosophers as visionaries and daydreamers. Due to this negative characterization of the ideologists, the concept of ideology began to acquire a negative or even pejorative connotation that has survived to this day. For the semiotics of the French idéologues, see Rastier (1972), Busse and Trabant (eds. 1986), Schlieben-Lange et al. (eds. 1989-1994), Bernecker (1996), and Dräxler (1996).

Without any positive or negative connotations, ideology has been defined in a purely descriptive and not necessarily critical sense as any system of norms, values, beliefs, or Weltanschaung directing the social and political attitudes and actions of a group, a social class, or a society as a whole. In this value-neutral sense, Geertz (1973) calls ideology a 'cultural system', and Parsons (1951: 349) defines ideology as 'a system of beliefs held in common by the members of a collectivity ..., a system of ideas which is oriented to the evaluative integration of the collectivity'. This value-neutral concept of ideology, which comprises both true and false but also neither true nor false systems of ideas, is frequently connected to conservative or liberal views of social systems. However, even Lenin uses a value-neutral term when he speaks of the 'socialist ideologies' (cf. Dierse and Romberg 1976: 178).

The pejorative sense of ideology, first expressed by Napoleon, was taken up and philosophically redefined by Marx and Engels. For Marx and Engels, ideologies are systems of false ideas representing the consciousness of the ruling class and used to promote and legitimize its power. The ideas are false because they promote the interest of a particular class while pretending to be in the interest of society as a whole. In this sense, ideology is seen as an instrument of deceit and manipulation. It is sometimes associated with myth and opposed to science and truth. Those who adopt this critical view of ideology, however, have always refused to consider their own system of ideas an ideology. For them, ideology is the thought of others or even of the enemy, as Raymond Aron put it (cf. Reis 1993: 7), while their own system of ideas is always considered scientific and thus excluded from any suspicions.

Among the semioticians, too, there are some who describe ideology in a value-neutral way as any cultural or social sign system, while others define ideology critically as a hidden system of meaning in public messages requiring critical analysis. For semiotic approaches to ideology not discussed in the following, see Nattiez (1973), Carontini and Péraya 
(1975: 133-173), Coward and Ellis (1977), Zima (ed. 1977, 1981), Larrain (1980), Santaella (1996), Heim (1983), Nicholson (1986), Halsall and Rutland (eds. 1988), Zima (1989), and the special issue of Recherches sémiotiques/Semiotic Inquiry 11.2-3 (1991).

Semiotic approaches that adopt the value-neutral view of ideology focus on the sign nature of ideology and describe to what extent ideologies are semiotic systems. A classic among these approaches is the one of the Bakhtin circle (Gardiner 1992).

\section{Bakhtin's pansemiotic view of ideology}

The concept of ideology in the writings of the Bakhtin circle is a very broad one. According to Bakhtin and Medvedev, 'the branches of ideological creation [are] science, art, ethics, religion, etc.' (1928: 3). As Morris points out, this broad concept of ideology is not only characteristic of Bakhtin's writings, but of the Russian language in general: 'The Russian ideologiya is less politically colored than the English word "ideology".... It is not necessarily a consciously held political belief system; rather it can refer in a more general sense to the way in which members of a given social group view the world' (1994: 245).

Ideology, as defined by Bakhtin and Medvedev is a quasi-synonym of 'culture'. They write: 'All the products of ideological creation - works of art, scientific works, religious symbols and rites, etc. - are material things, part of the practical reality that surrounds man' (1928: 7). The study of ideologies in this broad conception is a study of signs and sign systems: 'There is no meaning outside the social communication of understanding ... Social intercourse is the medium in which the ideological phenomenon first acquires its specific existence, its ideological meaning, its semiotic nature' (1928: 8-9).

This pansemiotic view of ideology is expressed most clearly by Voloshinov, who argues: 'Everything ideological possesses meaning: it represents, depicts, or stands for something lying outside itself. In other words, it is a sign. Without signs, there is no ideology' (1930: 9). Vice versa, Voloshinov also concludes that all signs are imbued with ideology and that ideology is hence at the root of semiosis:

A sign does not simply exist as a part of a reality - it reflects and refracts another reality. Therefore, it may distort that reality or be true to it, or may perceive it from a special point of view, and so forth. Every sign is subject to the criteria of ideological evaluation (i.e., whether it is true, false, correct, fair, good, etc.). The domain of ideology coincides with the domain of signs. They equate with one 
another. Wherever a sign is present, ideology is present, too. Everything ideological possesses semiotic value. (Voloshinov 1930: 10)

In spite of the all-pervasive presence of ideology, discourse must not be seen as the manifestation of ideological uniformity. The idea of ideology as a normative force is incompatible with Bakhtin's theory of dialogics and textual openness ('unfinalizability'). Instead of being ideologically uniform, texts are ployphonous. Textual polyphony is the result of a 'heteroglossic' plurality of voices, which creates a plurality of possible meanings. Rather than being homogeneous, texts evince a 'double-voiced discourse' with [at least] 'two voices, two meanings, and two expressions' (Bakhtin 1937-38: 301, 324).

\section{The nature of the ideological sign and the idiologeme}

While the Bakhtin circle postulates the all-pervasiveness of ideology in signs, most other semioticians find it necessary to distinguish between ideological and nonideological discourse. Semiotic tools in the analysis of ideological discourse in this tradition have been concepts such as connotation (see below), symbol, semiotic value, and norm. According to Nadin (1981: 236), e.g., ideology is 'simultaneously representation (Peirce's ideoscopy) and norm of the world', and it has a 'predominantly symbolic character' (1981: 237).

Ponzio (1993: 61-62), by contrast, emphasizes both the indexical and the iconic aspects of ideologies. The former is due to the indirectness of any ideological discourse, while the latter results from the feature of similarity inherent in ideological conformity and repetition of the ideologically given. From a different perspective, Marty (1990: 344) interprets the same feature of ideological uniformity on the basis of Peirce's semiotics as the effect of ideological legisigns, which tend to determine sinsigns.

The aspect of evaluation is central to Reis's (1993: 31) definition of the ideological sign as a sign whose meaning is axiological. Axiology is also the key term in Greimas's and Courtés's (1979: 149) semiotic theory of ideology, according to which ideological meanings are textual actants manifesting values of a deep structural axiological system.

The question of the semiotically minimal unit of ideological discourse has been of concern to early studies by Bakhtin, Medvedev, and Kristeva, who agree that such a unit of discourse analysis should be defined as 'ideologeme'. In the pansemiotic view of the Bakhtin circle, the ideologeme is practically any sign in human communication. Because it is 'an inseparable element of the unified ideological horizon of the social group' 
(Bakhtin and Medvedev 1928: 21), 'every word betrays the ideology of its speaker ..., every speaker, therefore is an ideologue, and every utterance an ideologeme' (Bakhtin 1937-38: 429).

In Kristeva's semanalysis (1969: 113-114), the ideologeme is an intertextual function. It serves 'to restructure an existing textual organization (of a semiotic practice) and its propositions (sequences), and assimilates them within their boundaries'. The ideologeme 'develops in the process of reading a text ... and provides its socio-historical coordinates'. The ideologeme, in this definition, is not a unit of text constitution but manifests itself in the text as a whole: 'The textual ideologeme is the focal point in which the transformation of the propositions (to which the text cannot be reduced) appear as a totality (as a text)' (Kristeva 1969: 113-114).

With these features, the semiotic study of ideology becomes a matter of studying a semiotic system and not of its elements. A semiotic definition along these lines is the one by Althusser (1975: 238). According to him, ideology is a 'system ... of representations (pictures, myths, ideas, or concepts), existing in a given society and fulfilling a historical role. Furthermore, ideology belongs to the unconscious of a society, and it is thus like the system of language (langue) that does not enter the speaker's consciousness in the process of speaking (parole) (Schiwy 1969: 76).

Verón (1978: 15), too, pursues the analogy between ideology and the system of language. Ideology is like a langue whose parole is manifested in ideological discourse. Hence, it is not a 'repertoire of contents but a grammar of sense' or 'a system of semantic rules to generate messages' (Verón 1971: 68).

\section{Semiotic unmasking of ideological discourse}

Among the discourse critical approaches to ideology, some focus on the semantics of individual messages in which they try to reveal symptoms of ideology in the form of secondary layers of meaning, while others are more concerned with the characteristics of ideologies as codes.

Semioticians who conceive of ideology as a secondary message have cherished the hope that by discovering and studying such secondary layers of ideological meaning it might be possible to reveal a primary level of textual meaning free of any ideological bias. The classical instrument of semioticians who approach the study of ideology in this way is Hjelmslev's dichotomy of denotation versus connotation (cf. KerbratOrecchioni 1977: 208-233; Reboul 1980: 136-140).

The theory of ideology as a textual connotation became popular with Roland Barthes's early critical studies of the mass media. Barthes defines 
ideology as a secondary semiotic system that adds connotations to a primary, denotative message. The 'common domain of the signifieds of connotation is that of ideology, which cannot but be single for a given society and history, no matter what signifiers of connotation it may use' (Barthes 1964: 49). Ideological connotations are hidden and want to remain concealed to become inaccessible to criticism. The ideological connotations hidden in the mass media aim at making social structures appear natural and inevitable in order to conceal their arbitrariness and conventionality.

Reboul (1980: 57-59), inspired by Barthes, studies ideology on the basis of a distinction between denotation as 'that, of which we speak' and connotation as 'the meaning given to it'. More specifically, he defines ideology as a kind of reification, because ideological discourse creates its own connotations by making concepts or words to objects without admitting that referential objects are really culture specific and hence not 'objective', but relative. In ideologies, the referential function of discourse appears as dominant, while all traces of the expressive function and the circumstances of the utterance are concealed (Reboul 1980: 53).

The idea of disguise inherent in this line of thought has been reinterpreted in categories of semiotic structuralism by Prieto (1975: 143-165). Prieto's approach is based on the structuralist principle of pertinence, according to which the essence of a structure can never be recognized in itself but only insofar as there is a pertinent difference in relation to some other structures: 'The way a subject perceives a material object ... presupposes a particular way of perceiving another object deriving from another universe of discourse' (Prieto 1975: 147). In accordance with this structuralist principle, Prieto argues that objective knowledge in the humanities requires reference to the historicity, conventionality, and arbitrariness of knowledge, a reference that must always reveal the possible alternatives to any semiotic state of affair. In contrast to methods of analysis which aim at revealing not only structures but also their structural alternatives, ideologies attempt to 'naturalize' social and cultural knowledge of material reality by making such knowledge appear a necessary consequence of the object in question (cf. Prieto 1975: 160). In this way, ideology disguises its own semiotic foundations.

The connotative theory of ideology came to a crisis when Barthes himself, in the 1970s, came to the conclusion that the distinction between connotative, ideological meaning and a denotative meaning free from ideology is rather problematic. In the end, Barthes gave up the idea of an ideology-free 'zero level' of the text and with it the connotative theory of ideology. That the principle of connotation suffered from too much generality is apparent when one considers that it also served indiscriminately 
as a tool in Barthes's study of myth (cf. Silverman 1983: 30). However, a possible differentiation but also a further parallel between ideology and myth have been suggested by Larrain (1980: 145, 150) with reference to Lévi-Strauss's theory of myth: 'The difference is located in the fact that ideology tries to solve social contradictions and myth tries to solve contradictions with nature'. What they have in common is that both myth and ideology are phenomena operating in the unconscious.

\section{Ideology as a code}

The models of the code and of the codification of meaning in language have been tools in semiotic approaches to ideology that focus on ideologies as systems of norms and beliefs (Reboul 1980: 160-183).

Against the background of information theory, Umberto Eco describes ideologies as codes generating connotative messages. According to Eco (1970: 553-554), an ideology creates 'a "sclerotic" message which has become a sign vehicle pertaining to a rhetorical code; this sign vehicle connotes a certain meaning as semantic unit of an ideological code ... [which] prevents us from seeing the semantic systems in the totality of their mutual relationships' (Eco 1970: 553-554) by restricting the field of possible connotations to the ones determined by the ideological code and by concealing all other connotations. Later, Eco describes ideology as an instance of overcoding, i.e., a process where (secondary) meanings are assigned to messages generated by a basic (primary) code (Eco 1976).

In a still more technical sense, the model of information theory has been Rossi-Landi's source of inspiration in his semiotic analysis of ideology. Rossi-Landi (1972: 122) uses key terms of information theory, such as redundancy and code control, to define ideology as a particular kind of message transmission: 'Messages which the audience can decode "immediately and easily" and with which they can identify, i.e., absorb as the ruling ideology, are those whose redundancy is sufficiently great to suppress the noise or the interferences which may disturb their reception.... The ruling class is the one which has the control over the emission and circulation of the constitutive verbal and nonverbal messages of a given community. The ruling class increases the redundancy of those messages which confirm their position.'

Parallels to Eco's view of ideology as the source of sclerotically codified messages can be found in the semiotics of the Tel Quel Group of the 1970s. As Eagleton (1991: 196-197) summarizes, ideology, according to Tel Quel, 
is essentially a matter of 'fixing' the otherwise inexhaustible process of signification around certain dominant signifiers, with which the individual subject can then identify. Language itself is infinitely productive; but this incessant productivity can be artificially arrested into 'closure' - into a sealed world of ideological stability, which repels the disruptive, decentered forces of language in the name of an imaginary unity. Signs are ranked by a certain covert violence into rigidly hierarchical order.... The process of forging 'representations' always involves this arbitrary closing off of the signifying chain, constricting the free play of the signifier to a spuriously determinate meaning which can then be received by the subject as natural and inevitable. (Eagleton 1991: 196-197)

Ideology is apparent not only in the messages of the mass media, but also in the language code used to generate these messages. This is the argument defended within the sociosemiotic framework of critical linguistics (Kress and Hodge 1979; Hodge and Kress 1988: 81). Kress supports the theory that not only is ideology reflected in the language of the media in the meanings conveyed by verbal messages, but also that ideological structures are codified in the grammatical system of a language. Kress (1985: 7) subscribes to the Whorfian hypothesis that 'the grammar of a language is its theory of reality'. Not only lexical semantics, but also syntactic structures of texts reveal ideological points of view to be disguised. Syntactic forms, such as active or passive voice, convey ideological perspectives and are hence the indexical signs of an ideology (Kress 1985: 31).

\section{Ideology of semiotics}

If 'every discourse is of an ideological kind', as Rossi-Landi (1968: 95) claims, the question of the ideological foundations of semiotic discourse arises as a metasemiotic problem. Does not every semiotic theory and hence also every semiotic theory of ideology have its foundation in some ideology, as Joseph and Taylor (1990) have argued in linguistics?

Rossi-Landi's (1972: 9) answer to this question is that 'on the one hand, a doctrine of ideologies without semiotics is incapable of articulating itself sufficiently.... On the other hand, semiotics, without the support of a doctrine of the ideologies, remains a specialized discipline, without any connection with practice, in spite of its claim to be a general theory of signs'.

While many semioticians acknowledge the impossibility of escaping from their own ideological point of view, there have been some proposals to demonstrate how a 'neutralization' of the semioticians' ideological bias may be possible. Verón, e.g., admits that the ideal of pure, objective scientific knowledge cannot be attained, but he claims that a scholarly 
approach may nevertheless be a method of neutralizing the given ideological perspective. According to Verón (1971: 71), ideology is both similar and opposed to science: Scientists presenting unverifiable results act ideologically. Science, by contrast, unlike ideology, makes an 'effort towards a neutralization of the connotations by making explicit the underlying decisions'.

Kristeva (1975: 703) has also recognized the danger of neglecting 'the question of the presuppositions or the ideology which authorize the application of a [scientific] formalization and ultimately its validity and truth'. At the same time, she points out that by investigating ideology, semiotics 'attacks itself at those same matrices which make the process of cognition possible: the sign, the subject, and its sociohistorical position'. Kristeva's own escape from this metatheoretical dilemma is in her postulate of an autocritical point of view, which will constantly question its own theoretical and ideological presuppositions.

\section{References}

Althusser, Louis (1975). For Marx, B. Brewster (trans.). New York: Pantheon.

Bakhtin, Mikhail M. ([1937-1938] 1981). The Dialogic Imagination, M. Holquist (ed.), C. Emerson and M. Holquist (trans.). Austin: University of Texas Press.

Bakhtin, Mikhail M. and Pavel N. Medvedev. ([1928] 1978). Formal'nyj metod v literaturovedenii. Leningrad: Priboi. [The Formal Method in Literary Scholarship. Eng. trans. by A. G. Wehrle. Baltimore: Johns Hopkins Press.]

Barthes, Roland (1964). Rhétorique de l'image. Communications 4: 40-51. [Also in Barthes (1977). Image - Music - Text, S. Heath (trans.), 28-46. New York: Hill \& Wang.]

Bernecker, Roland (1996). Die Rezeption der 'idéologie' in Italien. Münster: Nodus.

Busse, Winfried and Jürgen Trabant (eds.) (1986). Les idéologues: Sémiotique, théories et politiques linguistiques. Amsterdam: Benjamins.

Carontini, Enrico and Péraya, Daniel (1975). Le projet sémiotique. Paris: Delarge.

Choe, Hyondok (1997). Ideologie: Eine Geschichte der Entstehung des Begriffs. Frankfurt/ Main: Lang.

Coward, Rosalind and Ellis, John (1977). Language and Materialism: Developments in Semiology and the Theory of the Subject. London: Routledge.

Dierse, U. and Romberg, R. (1976). Ideologie. In Historisches Wörterbuch der Philosophie, vols. 1-9 (1971-1996), J. Ritter and K. Gründer (eds.), vol. 4, 158-186. Basel: Schwabe.

Dräxler, Hans-Dieter (1996). Die 'Idéologie' in Deutschland. Münster: Nodus.

Eagleton, Terry (1991). Ideology. London: Verso.

Eco, Umberto (1970). Codes and ideology. In Linguaggi nella società e nella tecnica, 545557. Milan: Ed. Comunità.

-(1976). A Theory of Semiotics. Bloomington: Indiana University Press.

Gardiner, Michael (1992). The Dialogics of Critique: M. M. Bakhtin and the Theory of Ideology. London: Routledge.

Geertz, Clifford (1973). The Interpretation of Cultures. New York: Basic Books.

Greimas, Algirdas Julien and Courtés, Joseph (1979 and 1986). Sémiotique: Dictionnaire raisonné de la théorie du langage, 2 vols. Paris: Hachette. 
Halsall, Albert W. and Rutland, Barry R. (eds.) (1988). Text and Ideology (=Centre Tadac Papers 1). Ottawa: Carleton University.

Heim, Robert (1983). Semiologie und historischer Materialismus. Cologne: Pahl-Rugenstein. Hodge, Robert and Kress, Gunther (1988). Social Semiotics. Cambridge: Polity Press.

Joseph, John E. and Taylor, Talbot J. (eds.) (1990). Ideologies of Language. London: Routledge.

Kerbrat-Orecchioni, Catherine (1977). La connotation. Lyon: Presses Universite.

Kress, Gunther (1985). Ideological structures in discourse. In Handbook of Discourse Analysis, 4 vols., Teun A. van Dijk, (ed.), 27-42. London: Academic Press.

Kress, Gunther and Hodge, Robert (1979). Language as Ideology. London: Routledge.

Kristeva, Julia (1969). Shmeiwtikh: Recherches pour une sémanalyse. Paris: Seuil.

-([1975] 1985). Sémiologie. In Encyclopaedia universalis, vol. 16, 703-706.

Larrain, Jorge (1980). The Concept of Ideology. Athens: University of Georgia Press.

Marty, Robert (1990). L'algèbre des signes: Essai de sémiotique scientifique d'après Charles S. Peirce. Amsterdam: Benjamins.

Morris, Pam (1994). A glossary of key terms. In The Bakhtin Reader, P. Morris (ed.), 245252. London: Arnold.

Nadin, Mihai (1981). Zeichen und Wert. Tübingen: Narr.

Nattiez, Jean-Jacques (1973). Problèmes sémiologiques de l'analyse des idéologies. Sociologie et sociétés 5 (2), 71-89.

Nicholson, Jane A. (1986). The ideological function in semiosis. In Semiotics 1985, J. N. Deely (ed.), 382-389. Lanham: University Press of America.

Parsons, Talcott (1951). The Social System. London: Routledge and Kegan.

Plamenatz, John ([1970] 1971). Ideology. London: Macmillan.

Ponzio, Augusto (1993). Signs, Dialogue, and Ideology, S. Petrilli (trans. and ed.). Amsterdam: Benjamins.

Prieto, Luis (1975). Pertinence et pratique. Paris: Minuit.

Rastier, François (1972). Idéologie et théorie des signes. The Hague: Mouton.

Reboul, Olivier (1980). Langage et idéologie. Paris: Presses University de France.

Reis, Carlos (1993). Towards a Semiotics of Ideology. Berlin: Mouton de Gruyter.

Rossi-Landi, Ferruccio (1968). Il linguaggio come lavoro e come mercato. Milan: Bompiani.

-(1972). Semiotica e ideologia. Milan: Bompiani.

- [(1982) 1990]. Marxism and Ideology, R. Griffin (trans.). Oxford: Clarendon.

Santaella, Lucia (1996). Produção de linguagem e ideologia, 2nd ed. São Paulo: Cortez.

Schiwy, Günther ([1969] 1984). Der französische Strukturalismus. Reinbek: Rowohlt.

Schlieben-Lange, Brigitte et al. (eds.) (1989, 1991, 1992, 1994). Europäische Sprachwissenschaft um 1800: Methodologische und historiographische Beiträge zum Umkreis der 'idéologie', 4 vols. Münster: Nodus.

Silverman, Kaja (1983). The Subject of Semiotics. New York: Oxford University Press.

Thompson, John B. (1990). Ideology and Modern Culture. Stanford: University Press.

Verón, Eliseo (1971). Ideology and social sciences. Semiotica 3: 59-76.

- (1978). Sémiosis de l'idéologique et du pouvoir. Communications 28: 7-20.

Voloshinov, Valentin N. (=Bakhtin, Mikhail) ([1930] 1973). Marxism and the Philosophy of

Language, L. Matejka and I. R. Titunik (trans.). New York: Seminar Press.

Zima, Peter V. (ed.) (1977). Textsemiotik als Ideologiekritik. Frankfurt/Main: Suhrkamp.

- (ed.) (1981a). Semiotics and Dialectics. Amsterdam: Benjamins.

- (1981b). Semiotics, dialectics, and critical theory. In Semiotics and Dialectics, Zima (ed.).

3-36. Amsterdam: Benjamins.

-(1989). Ideologie und Theorie. Tübingen: Francke. 
Winfried Nöth (b. 1944) is Professor of Linguistics and Semiotics and Director of the Interdisciplinary Center for Cultural Studies at the University of Kassel, Visiting Professor at the Catholic University of São Paulo (PUC), Honorary Member of the International Association for Visual Semiotics, and President of the German Association for Semiotic Studies 〈noeth@uni-kassel.de〉. He has written on a large number of topics in Theoretical and Applied Semiotics. His 160 articles, eleven authored books, and five edited books are on topics concerning semiotic aspects of aesthetics, linguistics, literature and culture, the media, advertising, maps, the image (with Lucia Santaella), the evolution of semiosis, and systems theory. His Handbook of Semiotics (1990) was awarded the Choice Outstanding Academic Book prize in 1992. The most important books edited by Nöth are Origins of Semiosis (1994), Semiotics of the Media (1997), Medientheorie und die digitalen Medien (with K. Wenz, 1998), Semiotics of Nature (with K. Kull, 2001), and The Crisis of Representation (special issue of Semiotica, with C. Ljungberg, 2003). 
Bereitgestellt von | Universitaetsbibliothek Kassel Angemeldet:

Heruntergeladen am | 17.12.14 14:50 